Vol 2 No 1 Juli 2021

Jurnal AlphaEuclidEdu

Received:13/04/2021; Resived:21/06/2021; Accepted:11/07/2021

\title{
KEMAMPUAN BERPIKIR ALJABAR DALAM MENYELESAIKAN SOAL MATERI TEOREMA PHYTAGORAS
}

\author{
${ }^{1}$ Avivah aulia, ${ }^{2}$ Mohamad Rif'at, ${ }^{3}$ Dwi Astuti \\ Program Studi Pendidikan Matematika FKIP Untan Pontianak \\ Email: avivah.awlia@gmail.co.id
}

\begin{abstract}
This research aims to determine the algebraic thinking skills of students in solving questionson the subject of the Pythagorean theorem in students of SMP Negeri 19 Pontianak. The research method used is descriptive method in the form of case studies. The subjects in this study were six students and the object in this study was the ability to think algebraically in solving problems on the subject of the Pythagorean theorem. The data collection techniquesused were test and nontest (interview). In this research, there is one student who achieves generational activities, two students in transformational activities and one student in globalmeta-level activities. In general, it can be concluded that the ability to think algebra in solving the problem of the Pythagorean theorem in SMP Negeri 19 Pontianak is that students are in transformational activities even though in generational activities students do not entirely write algebraic forms and equations. Students also have not been able to solve problems by writing down the rules used at each step, and not writing conclusions.
\end{abstract}

\section{Keywords : Algebraic Thinking Skills, Solve The Problem, Pythagorean Theorem}

\section{Pendahuluan}

Tujuan pembelajaran matematika menurut PERMENDIKBUD No. 22 Tahun 2016 sesuai Kurikulum 2013 terdiri dari: (1) memahami konsep matematika, menjelaskan keterkaitan serta mengaplikasikan konsepsecara efisien, luwes, akurat, dan tepat dalam memecahkan masalah, (2) menalar pola sifat dari matematika, memanipulasi matematika dalam membuat generalisasi, menata argumen, merumuskan bukti atau menjelaskan gagasan dan pernyataan matematik, (3) memecahkan masalah yang meliputi kesanggupan memahami masalah, menyusun model penyelesaian matematika, menyelesaikan model matematika, dan memberikan solusi yag tepat, dan (4) mengkomunikasikan argumen dalam bentuk tabel, diagram, simbol, ataupun media lainnyayang dapat memerjelas permasalahan ataupunkeadaan.

Menurut tujuan pembelajaran matematika tersebut, dapat disimpulkan bahwa setelah mengikuti pembelajaran matematika peserta didik harus mampu memahami konsep dan menerapkan konsep matematika, melakukan manipulasi matematika, memecahkan permasalahan serta menggambarkan atau mengkomunikasikan argumen kedalam bentuk tabel, diagram, simbol, atau media lainnya. Mempelajari matematika tidak berupa menghitung semata, tetapi siswa diharapkan mampu bernalar, berpikir kritis serta logis, dapat melakukan manipulasi aljabar, mampu membuat generalisasi dari data yang ada, menyelesaikan masalah dalam bidang ilmulain serta masalah dalam kehidupan sehari- hari. Maka berpikir aljabar merupakan satu diantara kompetensi yang penting dimiliki siswa.

Berpikir aljabar bagi Kieran (2004: 149), merupakan cara berpikir yang melibatkan perkembangan cara berpikir menggunakan simbol-simbol aljabar. Kieran (2004: 141- 142) juga menjelaskan bahwa kategori kesanggupan berpikir aljabar siswa melingkupi: (1) aktivitas generasional melibatkan pembentukan persamaan dan 
Vol 2 No 1 Juli 2021

Jurnal AlphaEuclidEdu

Received:13/04/2021; Resived:21/06/2021; Accepted:11/07/2021

ekspresi yang menjadi objek aljabar; (2) aktivitas transformasi, berkaitan dengan mengubah bentuk ekspresi atau persamaan yang berbasis pada aturan; dan (3) aktivitas level-meta global, melibatkan aljabar sebagai suatu alat baik dalam memecahkan persoalan aljabar maupun persoalan lain.Kriegler (2011: 10) mengatakan bahwa aljabar ialah pintu gerbang untuk memahami matematika lebih lanjut. Dengan aljabar pula, siswa dikenalkan berbagai simbol matematika dan variabel yang bisa digunakan untuk menyederhanakan kalimat menjadi model matematika dalam menyelesaikan masalah yang berkaitan dengan kehidupan sehari-hari.Sedangkan NCTM (2000: 37) menyatakan bahwa aljabar penting dalam kehidupan orang dewasa baik pada pekerjaan dan sebagai persiapan untuk pendidikan yang lebih tinggi. Aljabar juga dapat diterapkan dalam kegiatansehari-hari.

Masa transisi dari berpikir aritmatika ke berpikir aljabar yang merupakan salah satu langkah yang paling sulit dialami siswa dalam belajar matematika dialami disaat siwa belajardi Sekolah Menengah Pertama (SMP)(Sukmawati, 2015:89); (Susgati et al., 2018).

Untuk menyelesaikan masalahmatematika sekolah maupun masalah kontekstual, siswa selalu memerlukan kesanggupan berpikir yang berhubungan dengan konsep aljabar seperti teorema Phytagoras.

Berdasarkan hasil nilai ulangan harian matematika pada kelas VIII G mengenai materi teorema Phytagoras, diperoleh databahwa hanya 3,7\% siswa dari 27 siswa yang mampu memperoleh nilai di atas Kriteria Ketuntasan Minimal (KKM) belajar yaitu 75 artinya hanya satu siswa tuntas. Menurut ketentuan kurikulum, suatu materi dikatakanketuntasan dicapai apabila siswa yang mencapai nilai KKM minimal sebanyak $80 \%$. Berdasarkan hasil wawancara terhadap salah satu guru yang mengajar matematikakelas VIII di SMP Negeri 19 Pontianak padatanggal 29 Maret 2020, siswa kurang memahami cara penyelesaian masalah padamateri teorema Phytagoras. Beberapa hambatannya adalah kesulitan siswa dalam mensubtitusikan nilai yang diketahui pada variabel yang terdapat pada suatu persamaan, kesulitan dalam mempresentasikan soal cerita kedalam bentuk persamaan, serta kesulitan dalam melakukan operasi dalam menyelesaikan persamaan aljabar seperti pada perkalian desimal.

Jika dikaitkan dengan kemampuan berpikir aljabar, ini menunjukkan bahwa kemampuan berpikir aljabar siswa masih rendah, karena masih belum memenuhi indicator berpikir aljabar.

Kemampuan berpikir aljabar diperlukan untuk pembelajaran matematika pada semua materi dalam menyelesaikan masalah baik itumasalah matematika maupun diluar matematika yang harus diselesaikan menggunakan konsep matematika, sehingga kemampuan berpikir aljabar sangat penting untuk dikuasai oleh siswa.

Melihat begitu pentingnya kemampuan berpikir aljabar dalam menyelesaikan masalah seperti yang diuraikan diatas, maka peneliti terdorong untuk melakukan penelitian tentang kemampuan berpikir aljabar dalam menyelesaikan soal pada materi teoremaPhytagoras pada siswa kelas IX SMPN 19 Pontianak. Tujuan pada penelitian ini untuk mengetahui kemampuan berpikir aljabar siswa dlm menyelesaikan soal kontekstual yang berhubungan dengan materi teorema Phytagoras.

\section{Metode Penelitian}


Vol 2 No 1 Juli 2021

Jurnal AlphaEuclidEdu

Received:13/04/2021; Resived:21/06/2021; Accepted:11/07/2021

Metode yang digunakan dalam penelitian ini ialah metode deskriptif, karena pada penelitian kali ini ialah untuk menguraikan kemampuan berpikir aljabar dalam menyelesaikan soal yang dimiliki siswa.

Subjek penelitian sebanyak enam siswakelas IX di SMP Negeri 19 Pontianak yg berkemampuan matematika tinggi, sedang dan rendah, masing-masing diambil dua siswa. Pemilihan subjek juga berdasarkan pertimbangan guru matematika yang mengajar disekolah tersebut, karena guru lebih mengetahui sikap serta kesanggupan komunikasi siswa sehingga ketika diadakan wawancara siswa mampu mengemukakan pendapatnya. Kemudian wawancara dilakukan untuk memperkuat hasil jawaban siswa. Objek penelitian ini yaitu kemampuan berpikir aljabar dalam menyelesaikan soal pada materi teorema Phytagoras.

Adapun jadwal kegiatan pengumpulandata tertera pada tabel dibawah ini:

Tabel 1. Jadwal Kegiatan Pengumpulan Data

\begin{tabular}{cccc}
\hline No. & Hari/Tanggal & Kegiatan & Tempat \\
\hline 1 & Selasa, 27 & Perizinan Uji Coba Soal dan & SMP Negeri 19 \\
& Oktober 2020 & Penelitian & SMP Negeri 19 \\
Pontianak
\end{tabular}

Teknik pengumpulan data dalampenelitian ini ialah tes dan non tes (wawancara). Alat pengumpulan data yang dipakai ialah soal tes kemampuan berpikir aljabar dan lembar wawancara. Tes kemampuan berpikir aljabar terdiri dari empat soal berbentuk esai yang disusun berdasarkan parameter berpikir aljabarsebagai berikut :

Tabel 2. Indikator Berpikir Aljabar

\begin{tabular}{|c|c|c|}
\hline No. & $\begin{array}{c}\text { Indikator Berpikir } \\
\text { Aljabar }\end{array}$ & Definisi Operasional \\
\hline 1 & Generasional & $\begin{array}{l}\text { Kegiatan siswa menuliskan ekspresi atau bentuk } \\
\text { persamaan dan aljabar yang menjadi objek aljabar } \\
\text { dari soal kontekstual yang berhubungan dengan } \\
\text { materi teorema Phytagoras. }\end{array}$ \\
\hline 2 & Transformasional & $\begin{array}{l}\text { Kegiatan siswa mampu untuk mengubah bentuk } \\
\text { persamaan atau ekspresi yang berbasis pada aturan } \\
\text { dalam menyelesaikan persamaan yang diperoleh } \\
\text { dari soal pada materi teorema Phytagoras tersebut. }\end{array}$ \\
\hline 3 & Level-meta Global & $\begin{array}{l}\text { Kegiatan siswa mampu untuk menyelesaikan soal } \\
\text { kontekstual yang berhubungan dengan materi } \\
\text { teorema Phytagoras berbantuan aljabar, dengan } \\
\text { langkah-langkah sebagai berikut: }\end{array}$ \\
\hline & \multirow{2}{*}{\multicolumn{2}{|c|}{$\begin{array}{l}\text { a. Menganalisis masalah yang diberikansehingga dapat memisahkan yang } \\
\text { diketahuidan ditanyakan. } \\
\text { b. Memisalkan sesuatu yang diketahui dan ditanyakan dengan variabel, } \\
\text { menganalisishubungan variabel hingga membentuk model matematika. }\end{array}$}} \\
\hline & & \\
\hline
\end{tabular}


Vol 2 No 1 Juli 2021

Jurnal AlphaEuclidEdu

Received:13/04/2021; Resived:21/06/2021; Accepted:11/07/2021

setiap proses penyelesaian sehingga diperoleh penyelesaian model matematika, serta

d. Membuat kesimpulan dari permasalahan yang diberikan dengan benar. Instrumen penelitian ini sudah melewatu uji validitas, reliabilitas, uji daya pembeda, derajat kesukaran dengan hasil yang dinyatakan valid dengan beberapa perbaikan dari validator yang terdiri dari satu dosen matematika FKIP Untan dan satu guru mata pelajaran matematika di SMP Negeri 19 Pontianak, koefisien validitas butir soal diperoleh pada nomor 1 dan 2 valid sejumlah 0,617, dan 0,864. Koefisien reliabilitas soal tergolong sedang sejumlah 0,52 , daya pembeda pada soal nomor 1 tergolong sedang sejumlah 0.,33, serta nomor 2 tergolong sedang sejumlah 0,3 . Derajat kesukaran pada soal nomor 1 tergolong mudah sejumlah 0,8 , serta nomor 2 tergolong cukup sejumlah 0,5 .

Teknik analisis data dalam penelitian ini dilakukan dalam proses penganalisisan data berupa: 1) reduksi data, 2) penyajian data, dan 3) penarikan kesimpulan.

\section{Hasil dan Pembahasan}

Hasil

Hasil yang diperoleh dari penelitian ini ialah hasil tes kemampuan berpikir aljabar dalam menyelesaikan soal materi teorema Phytagoras pada enam siswa SMP Negeri 19 Pontianak. Pemberian tes keampuan berpikir aljabar berupa dua soal pada hari Senin, 9 November 2020 dengan durasi pengerjaan 40 menit.

Hasil Tes Kemampuan Generasional Siswadalam Menyelesaikan Soal pada Materi Teorema Phytagoras.

Tabel 1. Data Hasil Jawaban Siswa pada Kemampuan Generasional di Kelas IXC SMP Negeri 19

Pontianak.

\begin{tabular}{cc}
\hline Jumlah Siswa & Hasil Jawaban Siswa \\
\hline 1 & Sesuai indikator \\
\hline 3 & Kurang sesuai indikator \\
\hline 2 & Tidak sesuai indikator
\end{tabular}

Berdasarkan Tabel 1, terlihat bahwa satu (16,7\%) dari enam siswa kelas IX C yang mampu menjawab sesuai dengan indikator kemampuan generasional, tiga (50\%) siswa yang menjawab kurang sesuai indikator kemampuan generasional, dan dua $(33,3 \%)$ siswa yang menjawab tidak sesuai indikator kemampuan generasional.

Hasil Tes Kemampuan Transformasional Siswa dalam Menyelesaikan Soal pada Materi Teorema Phytagoras.

Tabel 2. Data Hasil Jawaban Siswa pada Kemampuan Transformasional di Kelas IXC SMP Negeri 19 Pontianak.

\begin{tabular}{cc}
\hline Jumlah Siswa & Hasil Jawaban Siswa \\
\hline 2 & Sesuai indikator \\
\hline 3 & Kurang sesuai indikator \\
\hline 1 & Tidak sesuai indikator \\
\hline
\end{tabular}

Berdasarkan Tabel 2, terlihat bahwa dua $(33,3 \%)$ dari enam siswa kelas IX C yang mampu menjawab sesuai indikator kemampuan transformasional, tiga (50\%) siswa yang menjawab kurang sesuai indikator kemampuan transformasional, dan satu $(16,7 \%)$ siswa yang menjawab tidak sesuai indikator kemampuantransformasional. 
Vol 2 No 1 Juli 2021

Jurnal AlphaEuclidEdu

Received:13/04/2021; Resived:21/06/2021; Accepted:11/07/2021

Hasil Tes Kemampuan Level-meta Global Siswa dalam Menyelesaikan Soal pada Materi Teorema Phytagoras.

Tabel 3. Data Hasil Jawaban Siswa pada Kemampuan Level-meta Global di Kelas IXC SMP Negeri 19 Pontianak.

\begin{tabular}{cc}
\hline Jumlah Siswa & Hasil Jawaban Siswa \\
\hline 1 & Sesuai indikator \\
\hline 3 & Kurang sesuai indikator \\
\hline 2 & Tidak sesuai indikator \\
\hline
\end{tabular}

Berdasarkan Tabel 3, terlihat bahwa satu (16,7\%) dari enam siswa kelas IX C yang mampu menjawab sesuai indikator kemampuan berpikir level-meta global, tiga (50\%) siswa yang menjawab kurang sesuai indikator kemampuan berpikir level-meta global, dan dua $(33,3 \%)$ siswa yang menjawab tidak sesuai indikator kemampuan berpikir level-metaglobal.

\section{Pembahasan}

Berdasarkan tujuan penelitian, pada bagian ini akan diulas mengenai kemampuan berpikir aljabar dalam menyelesaikan soalmateri teorema Phytagoras pada siswa SMP Negeri 19 Pontianak. Pada penelitian ini, teorema Phytagoras menyatakan bahwa untuk setiap segitiga siku-siku berlaku kuadrat dari sisi terpanjang (hipotenusa) sama dengan jumlah kuadrat kedua panjang sisi siku-sikunya (Miyanto, 2019:3). Dari pernyataan yang dikemukakan Phytagoras, kemudian diilustrasikan dengan segitiga ABC sebagai berikut:

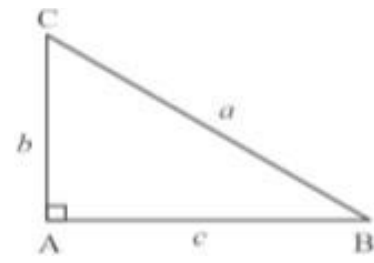

\section{Gambar 1. Segitiga Siku-siku ABC}

Jika $\mathrm{b}$ dan $\mathrm{c}$ adalah panjang sisi siku-siku pada segitiga, dan a adalah panjang sisi miring yang berada dihadapan sudut siku-sikunya. $a^{2}=b^{2}+c^{2}$ (Ellis, 2004: 32)

Pada penelitian ini, kemampuan berpikir aljabar dibagi menjadi tiga yaitu berdasarkan kemampuan generasional, kemampuan transformasional dan kemampuan level-meta global.

Berpikir aljabar didefinisikan oleh beberapa ahli seperti Discroll (1999: 143) menyatakan berpikir aljabar dapat diakui sebagai kapasitas untuk merepresentasi situasi kuantitatif sehingga terlihat relasi antar variabel. Ameron (2002: 8) mendefinisikan bahwa berpikir aljabar ialah proses mental dengan penalaran sesuatu yang belum diketahui, menggeneralisasi, dan membuat formula hubungan antara besaran- besaran dan membangun konsep variabel.

Kieran (2004: 149) berpendapat berpikir aljabar sebagai proses berpikir yang melibatkan perkembangan cara berpikir menggunakan simbol-simbol aljabar. Kategori berpikir aljabar (Kieran, 2004: 141-142); (Rif'at, 2014), pada siswa meliputi: (1) Aktivitas Generasional, meliputipenulisan ekspresi atau bentuk aljabar dan persamaan yang merupakan objek aljabar. Ekspresi atau bentuk aljabar (NCERT, 2019:137); (Widiani et al., 2016), terdiri dari variabel dan konstanta sedangkan persamaan adalah dua ekspresi yang bernilai sama dan dihubungkan dengan tanda sama dengan (=). Cirinya meliputi: (a) persamaan memuat sesuatu yang tidak diketahui yang merepresentasikan situasi masalah, (b) ekspresi generalisasi dari pola geometri atau 
Vol 2 No 1 Juli 2021

Jurnal AlphaEuclidEdu

Received:13/04/2021; Resived:21/06/2021; Accepted:11/07/2021

barisan bilangan, (c) ekspresi dari aturan yang mengatur hubungan numerik. Objek mendasar dari ekspresi dan persamaan adalah variabel dan sesuatu yang tidak diketahui, seperti halnya tanda sama dengan, sesuatu yang tidak diketahui dan notasi dari solusi persamaan. Sebagian besar pembentukkan makna untuk objek aljabar merupakan aktivitas generasional.; (2) aktivitas transformasional, meliputi perubahan suatu ekspresi atau persamaan yang berbasis pada aturan (mengenali bentuk aljabar, memfaktorkan, menjabarkan substitusi, menjumlahkan dan mengalikan ekspresi polinomial, menyelesaikan persamaan, menyederhanakan ekspresi, mengubah ekspresiatau persamaan menjadi ekspresi ataupersamaan yang ekuivalen), menentukanpenyelesaian dari suatu persamaan aljabar.

Aktivitas ini merupakan mengubah ekspresi atau persamaan untuk menyelesaikan masalah yang diperoleh.; (3) aktivitas level-meta global, menyertakan aljabar sebagai suatu alat baikdalam memecahkan persoalan aljabar maupunpersoalan lain diluar aljabar. Kegiatan ini antaralain memecahkan masalah, memodelkan, melihat struktur, mempelajari perubahan, menggeneralisasikan, menganalisis hubungan, memberikan alasan, membuktikan danmemprediksi suatu masalah.

Mengenai ini, menerangkan bahwa kemampuan berikir aljabar siswa yang baik apabila mampu memenuhi ketiga indikator dari berpikir aljabar. Berdasarkan data hasil jawaban siswa, diperoleh bahwa pada tahap generasional ialah siswa hanya menggambarkan sesuatu yang diperoleh dari soal yang diberikan tanpa menuliskan bentuk aljabar dan persamaan dari soal. Berdasarkan hasil wawancara terhadap dua siswa, dapat disimpulkan bahwa siswa jarang untuk menuliskan bentuk aljabar dengankata-kata serta persamaan yang digunakan. Siswa cenderung langsung mengerjakan soalsetelah memahaminya.

Kemudian pada tahap transformasional, berdasarkan hasil jawaban siswa dapat diketahui bahwa ada siswa yang menyelesaikan soal dengan hasil yang kurang tepat, ada siswa yang belum bisa menyelesaikan masalah dengan benar, ada siswa yang menyelesaikan kurang sesuai indikator karena tidak dapat menyelesaikan persamaan yang diperoleh. Berdasarkan hasil wawancara pada tahap transformasional, dapat disimpulkan bahwa siswa tidak dapat menyelesaikan soal yang diberikan karena siswa kurang menguasai perhitungan, serta tiga siswa ini masih belum mampu menuliskan aturan pada setiap langkah pengerjaan karena tidak terbiasa dalam menuliskan aturan yang digunakan, siswa terkadang langsung mengerjakan soal tanpa menuliskan aturan. Serta berdasarkan hasil jawaban siswa pada tahap level-meta global, ada siswa yang hanya menggambarkan hal yang diketahui tetapi tidak menuliskan bentuk aljabar dan persamaan yang diperoleh, kemudian masih kurang tepat dalam menyelesaikan persamaan, tidak dapat mencantumkan aturan yang digunakan serta tidak menuliskan kesimpulan yang di peroleh.

Berdasarkan hasil wawancara pada tahap level-meta global, hanya menggambarkan hal yang diketahui dan tidak menuliskan persamaan dari soal karena jarang menuliskan sesuatu yang diketahui dan ditanyakan, persamaan yang digunakan, tidak menuliskan alasan pada setiap langkah karena tidak terbiasa dalam menuliskan alasan pada setiap langkahnya dan sudah lupa dengan sifat operasi bilangan serta tidak menuliskan kesimpulan karena jika sudah mendapatkan hasil akhir, siswa langsung melanjutkan ke soalberikutnya.

Ada pula siswa yang menggambarkan sesuatu yang diperoleh dari soal tanpa 
Vol 2 No 1 Juli 2021

Jurnal AlphaEuclidEdu

Received:13/04/2021; Resived:21/06/2021; Accepted:11/07/2021

menuliskan bentuk aljabar dan persamaan dari soal, kurang tepat dalam menyelesaiikan persamaan serta tidak mencantumkan aturan yang digunakan. Berdasarkan hasil wawancara pada tahap level-meta global diketahui bahwa siswa setelah membaca soal kemudian menggambarkan hal yang diketahui, jarang dalam menuliskan sesuatu yang diketahui dan ditanyakan sertalangsung mengerjakan soal setelah memahami soal tanpa menuliskan persamaan yang digunakan, kurang teliti dalam mengerjakan serta lupa untuk menuliskan aturan yang digunakan. Dan satu siswa yang tidak sesuai indikator karena siswa langsung melakukan perhitungan tanpa menuliskan persamaan yang harusnya digunakan, sesuatu yang diketahui dan ditanyakan, aturan yang digunakan pada setiap langkah pengerjaan serta kesimpulan. Berdasarkan hasil wawancara pada tahap level meta global, diketahui bahwa siswa kebingungan dalam mengerjakan soal karena kurang memahami materi teorema Phytagoras. Siswa juga tidak pernah menuliskan keterangan sifat pada setiap langkahnya karena siswa sudah lupa dan tidak pernah menuliskan sifat operasi bilangan serta jarang menuliskan kesimpulan pada akhir pengerjaan.

\section{Simpulan dan Saran Simpulan}

Berdasarkan hasil analisis data, wawancara serta pembahasannya maka dapat disimpulkan secara umum bahwa kemapuan berpikir aljabarsiswa dalam menyelesaikan soal materi teoremaPhytagoras pada siswa SMP Negeri 19 Pontianak secara umum ialah siswa yang berada pada aktivitas transformasional walaupun pada kemampuan generasional siswa tidak seluruhnya menuliskan bentuk aljabar dan persamaan yang merupakan objek aljabar. Siswa juga belum mampu menyelesaikan masalah dengan mencantumkan aturan yang digunakan pada setiap langkahnya, serta tidak menuliskan kesimpulan.

Namun siswa mampu mengerjakan soal dengan tidak mencantumkan aturan yang digunakan pada setiap langkahnya serta tidak seluruh siswa menuliskan kesimpulan. Secara rinci dapat diberikan kesimpulan yang diperoleh dari penelitian ini sebagai berikut : 1) Kemampuan generasional siswa dalam menyelesaikan soal materi teorema Phytagoras pada siswa masih belum sesuai yang diharapkan, karena dari enam siswa hanya satu siswa yang menjawab sesuai indikator, tiga siswa yang menjawab kurang sesuai indikator dan dua siswa lainnnya tidak menjawab. Dua siswa yang memiliki kemampuan matematika tinggi menjawab kurang sesuai indikator karena hanya mengambarkan sesuatu yang diketahui dari soal tanpa menuliskan bentuk aljabar yang diperoleh. Siswa yang berkemampuanmatematika sedang dari dua hanya satu yang dapat menjawab sesuai indikator, sedangkan satunya hanya menuliskan sesuatu yang diketahui tanpa menuliskan bentuk aljabar dan persamaan yang diperoleh, serta dua siswa berkemampuan rendah tidakmenjawab.

Berdasarkan hasil wawancara, siswa tidak menuliskan sesuatu yang diketahui dalam bentuk ekspresi dan ditanyakan dalam bentuk persamaan karena siswa tidak terbiasa dalam menuliskannya. Menurut siswa, jika sudah memahami soal tidak perlu menuliskannya.; 2) Kemampuan transformasional siswa dalam menyelesaikan soal materi teorema Phytagoras masih belum sesuai yang diharapkan karena dari enam siswa terdapat dua siswa yang menjawab sesuai dengan indikator, tiga siswa yang kurang sesuai indikator, serta satu siswa lainnya tidak menjawab. Dua siswa yang 
Vol 2 No 1 Juli 2021

Jurnal AlphaEuclidEdu

Received:13/04/2021; Resived:21/06/2021; Accepted:11/07/2021

memiliki kemampuan matematika tinggi hanya satu siswa yang dapat menyelesaikan soal sesuai indikator sedangkan satu siswa lainnya kurang sesuai indikator karena terdapat kekeliruan dalam memberikan simbol pada tahap akhirnya hingga hasilnya kurang tepat dan tidak mencantumkan aturan pada tiap langkahnya. Dua siswa yang berkemampuan sedang hanya satu yang menjawab sesuai indikator, sedangkan satu lainnya kebingungan untuk melanjutkan pengerjaannya setelah mensubtitusikan nilai pada persamaan serta tidak mencantumkan aturan pada tiap langkahnya. Serta dua siswa berkemampuan rendah tidak menjawab.

Berdasarkan hasil wawancara, siswa tidak menyelesaikan perhitungan karena ada yang keliru dalam menuliskan simbol pada tahap akhir, ada yang miskonsepsi terkait konsep kuadrat. Siswa juga mampu menyelesaikan masalah walau tidak terbiasa dalam menuliskan alasan pada tiap langkah pengerjaannya. 3) Kemampuan level-meta global siswa dalam menyelesaikan soal materi teorema Phytagoras juga masih belum sesuai yang diharapkan, karena dari enam siswa hanya satu siswa yang menjawab sesuai indikator, tiga siswa yang menjawab kurang sesuaiindikator dan dua siswa lainya tidak menjawab. Dua siswa yang memiliki kemampuan matematika tinggi menjawab kurang sesuai indikator karena hanya menggambarkan sesuatu yang diketahui tanpa menuliskan bentuk aljabar dan persamaan yang diperoleh, kemudian langsung mengerjakan tanpa menggunakan persamaan yang diperlukan, tidak mencantumkan aturan yang digunakan pada tiap tahapnya, serta tidak menuliskan kesimpulan. Dua siswa yang berkemampuan sedang hanya satu yang dapat menjawab sesuai indikator dan satu lainnya tidak menjawab, serta dua siswa berkemampuan rendah juga tidak dapat menjawab soal kontekstual pada materi teorema Phytagoras. Berdasarkan hasil wawancara, siswa tidak menuliskan sesuatu yang diketahui dalam bentuk ekspresi dan ditanyakan dalam bentuk pesamaan karena siswa tidak terbiasa dalam menuliskannya. Menurut siswa, jika sudah memahami soal tidak perlu menuliskannya, melainkan langsung mengerjakannya. Menurut siswa juga tidak terbiasa untuk menuliskan alasan pada tiap langkahnya, tidak selalumenuliskan kesimpulan pada akhir penyelesaian soal. Saran

Berdasarkan hasil temuan dalam penelitian ini, saran yang dapat peneliti sampaikan ialah: 1) Siswa perlu untuk melatih kesanggupan berpikir aljabar yang dimilikinya dengan semakin banyak mengerjakan soal, maka kemampuan berpikir aljabar akan semakin baik; 2) Perlunya merancang pembelajaran yang dibutuhkan siswa untuk meningkatkan kemampuan berpikir aljabar yang dimilikinya.

\section{Referensi}

Ameron, Barbara Ann Van. (2002). Reinvention Of Early Algebra. Tesis. Universiteit Utrech, Nederlands.

Driscoll, M. 1999. Fostering Algebraic Thinking: A Guide for Teachers Grade 610.Portsmouth, NH, Heinemann. Tersedia di www.thetrc.org/trc/download/.../fosteringalg.pdf, [diakses tanggal 5 Juni 2020]

Julie, Ellis. (2004). What's Your Angle, Phytagoras?. (Online). (diakses tanggal 1 Agustus 2020).

Kriegler, S. (2011). "Just What is Algebraic Thingking?. Submitted for Algebraic Concepts in the Middle School."

Kieran, Carolyn. (2004). Algebraic Thinking in the Early Grades: What Is It? The 
Vol 2 No 1 Juli 2021

Jurnal AlphaEuclidEdu

Received:13/04/2021; Resived:21/06/2021; Accepted:11/07/2021

Mathematics Educator. Vol. 8. No. 1.

NCERT, 1961. Algebraic Expressions and Identities. Government of India.

NCTM, 2000. Principles and Standars for School Mathematics. United States of America : The NCTM, Inc.

Rif'at, M. (2014). Kajian Mengenai Representasi Visualistik dan Kemampuan Menyelesaikan Masalah Matematika. Jurnal Pendidikan Dasar, 2(2), 94-112.

Sudjana, Nana, dan Ibrahim, 1989, PenelitianKualitatif dan Kuantitatif, Rineka Cipta.

Sukmawati, Ati (2015). Berpikir Aljabar dalamMenyelesaikan Masalah Matematika.

Susgati, Suratman, D., \& Astuti, D. (2018). Bentuk-Bentuk Komunikasi Matematis Dalam Model Pembelajaran Geometri yang Dikembangkan Berdasar Tahapan Teori Van Hiele Di SMA. 1-13.

Widiani, T., Rif'at, M., \& Ujiddin, R. (2016). Penerapan Pendekatan Saintifik dan Pengaruhnya Terhadap Kemampuan Komunikasi Matematis dan Berpikir Kreatif Siswa. Jurnal Pendidikan Dan Pembelajaran Khatulistiwa, 5(1), 1-14. 